\title{
Peculiarities of RF Dairy Industry Development Under Food Embargo
}

Taira Velimagomedovna Murtuzalieva1

\author{
Maisa Emirovna Seifullaeva1 \\ Irina Petrovna Shirochenskaya ${ }^{1}$
}

\author{
${ }^{1}$ Department of Marketing, Plekhanov Russian University of Economics \\ Correspondence: Murtuzalieva Taira Velimagomedovna, 59-72 3-rd Parkovaya Street, Moscow, 105425
}

Russian Federation; E-mail: taira1973@yandex.ru

Doi:10.5901/mjss.2015.v6n5s4p526

\begin{abstract}
The article reveals absolute domination of import orientation in development of dairy industry within the framework of the research. This domination will cause industry deindustrialization and retardation of its potential. The article states that imposition of one-year food embargo used as a tool to ensure food security has a negative impact and can be considered as a destructive factor for the dairy industry development in current situation. The article substantiates that import limitation of dairy products against the background of state policy of price liberalization caused significant price decrease on dairy products and lead to decrease of production output within the industry by $50 \%$. The article states that adverse effect of food embargo would be multiplied by system problems of dairy industry and will provoke the threat of crisis as a factor of food security destabilization in RF. A system of optimization measures was proposed within the framework of the research in order to secure stability and to increase efficiency of dairy industry in RF. These optimization measures take the principle of emergence into consideration in order to carry out corporate management policy in the dairy industry and state economic policy in the food industry. Technical base modernization, building financial capacity of the industry and management strategy improvement is regarded as a ground for functional direction of the optimization measures. Introduction and practical realization of the proposed conceptual optimization measures will become the grounds for revolarisation of industry competiveness under market conditions and will formulate prerequisite for quality improvement of dairy products. All these factors will lead to stabilization of agro-industrial complex and provision of food security in the country.
\end{abstract}

Keywords: food embargo, dairy industry of RF, import of dairy products, food processing industry, foreign trade, import substitution.

\section{Introduction}

\subsection{Introduce the Problem}

Significance of dairy industry is conditioned by the importance of food processing industry. Being a system element of agro-industrial complex, it is regarded as a leading sphere of economy in Russian Federation. Dairy industry is an industry with a massive multiplier effect used to ensure increasing demand for high quality products. It has a huge impact on agriculture, transportation, retail and wholesale trade. The basis of its operation is to satisfy basic needs of the population for major food products, to provide a diversity of product range/assortment. At present 21,000 enterprises function in the dairy industry and related fields, 1,2 million people are employed in the industry; dairy products account for nearly 15\% in the turnover of Russian retailers (website of the RF Ministry of Agriculture, 2015.

In addition, functioning of the industry is closely connected to the state of the majority of industries in Russian Federation, especially to the development of agriculture as it takes the major stake in transporting goods in the country. Besides, milk and dairy products are included into the list of products that are subject to the Food Security Doctrine and are of primary importance in the nutrition of the population. (The Approval of Food Security Doctrine: Presidential Decree $\# 120,2010)$. Consequently, prolification levels of dairy industry are to be regarded as the factor of people's material wellbeing as well as the effectiveness of the agro-industrial complex.

\subsection{Importance of the Problem}

The development of dairy industry occurs under severe economic conditions due to international political and financial 
crisis. Active liberalization process of foreign trade activities taking place lately, large-scale imports of dairy products and sharp decline in effective demand on significant part of the population in Russia led to substantial reduction in dairy product consumption per capita.

As a result, the present state of dairy industry can be regarded as unsatisfactory. It occupies noncompetitive position with respect to imported food. Thereby, it seems urgent to study prospects and potential of dairy industry development in RF as a factor to increase national food security and industrial effectiveness under conditions of food embargo.

\subsection{Relevant Scholarship}

Many scientific papers of both overseas and Russian authors are devoted to the problem of fundamental impact of food embargo as an instrument of providing country's food security on food industry activities. Among them are A. Anishenko (Anishenko, 2015), V. Afonina (Afonina, 2014), D. Zerkalov (Zerkalov, 2009), T. Murtuzalieva (Murtuzalieva and Seifullaeva, 2014), M. Seifullaeva (Seifullaeva and Murtuzalieva, 2014), A. Pylypiv (. Pylypiv et. Al, 2014), D. Dawe (Dawe and oth., 2015), T. Hemme (Hemme and oth., 2014), G. Hufbauer (Hufbauer and oth., 1990), T. Murtuzalieva (Murtuzalieva, 2014), R. Piłat (Piłat, 2014), F. Zhiqiang (Zhiqiang, 2013) and others.

Meanwhile, scientific achievements alongside with vast practical experience within the framework of the discussed problem still leave room for discussion of both theoretical as well as practical character and require further scientific research.

In particular, the issues regarding the impact of food embargo as a tool of protectionism on food industry and prospective development of dairy industry as a part of food industry viewed from the perspective of food security of RF have not yet received full coverage.

\subsection{State Hypotheses and Their Correspondence to Research Design}

With the reference to debatable and polemist nature of conceptual approaches to the solution of this scientific problem, the aim of the research is to reveal and identify the nature of food embargo impact on food security provision in Russia, in particular, dairy industry. The research is conducted with the purpose of developing theoretical and conceptual recommendations aimed at improving the efficiency of the industry.

The aim of the article predetermined the formulation and solution of certain conceptual issues of empirical research:

To analyze the current state of dairy market and to determine peculiar properties of RF dairy industry development within the framework of food security provision;

To provide reasons for food embargo impact on dairy industry operation viewed as a policy of governmental support of national dairy producer;

To develop and substantiate major prospective directions in dairy industry as a constituent part of the state agroindustrial complex and factors of food security provision.

\section{Method}

Certain general and specific methods of research were used in order to achieve the aims and to solve conceptual tasks.

\subsection{Method of statistical observation}

The method of random statistical observation was used in the research. The observation was conducted by means of scientifically collected quantitate information on indicators of dairy industry trade balance, structure and dynamics of the imports of basic dairy products, average purchase price of raw milk and indicators of dairy products output in PF. On this basis source database was formulated with the aim to evaluate current state of dairy industry under economic embargo. Data systematization on the global raw milk output for the researched period made it possible to generate array of information in order to evaluate Russian dairy industry significance within the global economy. Data collection on qualitative laws of influence on import restrictions became the basis for attributive assessment of the nature of such influence on dairy industry operation. 


\subsection{Methods of analysis and measurement}

Dynamic range of absolute and relative indicators was formed, based on statistical summary of quantitative data concerning the state of dairy industry under economic embargo by means of statistic measurements.

This dynamic range was formulated in order to identify share of countries in the world output of cow milk, the structure of dairy industry trade balance, the structure of basic product import within the industry, import tendencies under embargo restrictions, the structure of dairy import, average annual prices and integral character of basic dairy product output.

\subsection{Method of taxonomic analysis}

Based on the procedure of bringing together multidimensional statistic data on production volumes of basic dairy products for the period of January-March 2014 and 2015, the single quantitative data characterizing dairy production in Russia for the researched period was calculated. It was calculated in the form of synthetic indicator or taxonomic indicator of development.

\subsection{Method of empirical generalization and logical reasoning}

Cognitive process made it possible to identify and denote empiric nature of destructive impact of embargo on dairy industry development in spite of relatively stable nature of food industry functioning.

By means of denoting peculiarities of development and the current state of dairy industry trade balance, the structure of basic product import within the industry, import tendencies under embargo restrictions, the structure of dairy import, average annual prices for raw milk and integral character of basic dairy product output, the authors propose some conceptual recommendations based on logical reasoning. The recommendations are aimed at improving efficiency of dairy industry operation in PF.

\section{Results}

At present Russian Federation is supposed to be one of the biggest world milk producers on food market. Thus, according to statistical data, Russia was ranked as one of the leaders in milk production by the beginning of 2015 that is $6 \%$ of world's output. It occupied the 3-rd position along with such leading milk producers as China, Brazil and Germany and gave primacy only to such milk giants as the USA and India (see. Fig. 1).

Basing our assumptions on these data we can state that Russia has great potential of agricultural production for ensuring both domestic needs and selling its products on foreign markets.

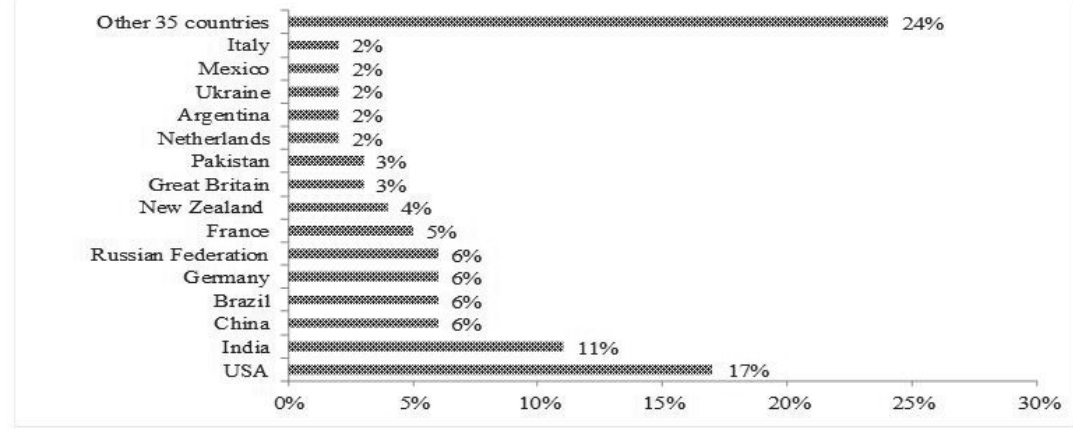

Figure 1. Share of countries in the world output of cow milk, data are as of 2014. (Completed by the authors, based on materials on world milk producers in 2015)

At the same time, despite vast potential of industry development and meeting the needs for dairy products on the domestic market, Russia turns out to be a nearly net importer of these goods. Thus, foreign trade structure of dairy 
industry can be characterized by significant dominance of import, attested by the negative foreign trade balance of the industry. In addition, a tendency for increased disproportion in of foreign trade structure can be observed. For the last 5 years, from 2009 to 2014 increase in imports accounted for 727, 4\%, whereas dairy export for the accounted period increased by only $24 \%$ (see fig.2).

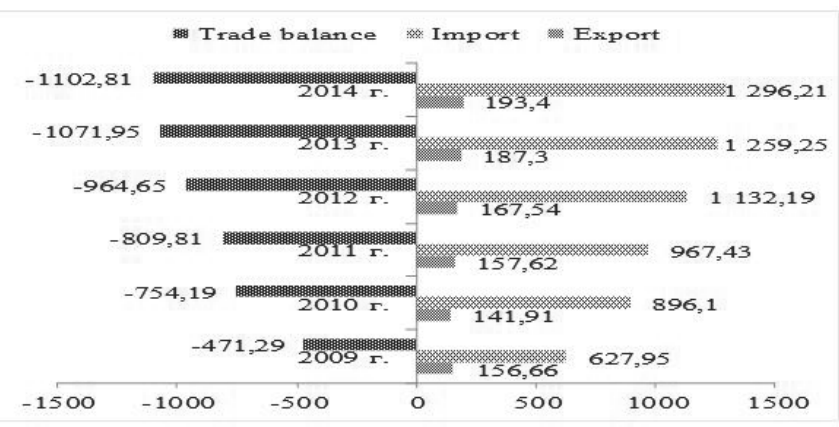

Figure 2. Indicators of external trade balance of dairy industry, thousand tones. (Completed by the authors, based on materials (Website of National Union of Milk Producers, 2015; Website of Russian Union of Enterprises of Diary industry; Website of Federal State Statistics Service, 2015))

Further development of the tendency to increase import of dairy products poses a serious threat for food security of the country, since continuous decrease of output will result in zero trade balance of dairy industry.

This in its turn can cause the undermining of Russia's macroeconomic stability.

Thus, in accordance with Food Security Doctrine of 2010, thresholds of the share of milk and dairy products (in terms of milk) should account for not less than $90 \%$ of the total production. (Food Security Doctrine - Presidential Decree $\# 120,2010)$. Today in accordance with the data provided by Federal State Statistics Service, the rate of self-provision by groups of dairy products regarded as necessary from food security point of view accounted for $76,6 \%$ in 2013 and $76,8 \%$, in 2014. These figures indicate the existence threat to food security of Russia. (Website of Federal State Statistics Service, 2015).

At present in order to provide support to Russian producers, the state has various instruments in possession. Thus, the National Project for the Development of Agro-industrial Complex was substituted by the National Program for Agricultural Development in 2008 (now it is called State Program in Agriculture for 2013-2020). To ensure independence in food sector is seen as one of the main goals of the Program. (State Program for the Development of Agriculture and Regulation of Agricultural Markets, Raw materials and Products for 2013-2020, 2015).

Food Security Doctrine was adopted in 2010 (Food Security Doctrine - Presidential Decree \#120, 2010) and Strategy for Development of Food and Processing Industry in Russian Federation was adopted in 2012 (Government Order N 559-p, April 17, 2012).

From August 7, 2014 in accordance with the Presidential Decree, dated August 6, 2014 \#560 named "On Application of Special Certain Measures to Ensure Security in RF", food embargo was introduced for the period of a year as a response to EU, US and Norwegian sanctions. The sanctions were used against import of agricultural products, raw materials and food products from these countries. (Presidential Decree \# 560, 2014).

Food embargo is seen as the most large-scale restriction on agricultural import since the time when import substitution policy was realized in Russia. Besides, this is the first restriction of this type introduced with the purpose of ensuring food security. In addition, it seems to be the most effective measure from the first glance - to support local producers and can result in accelerating import substitution and early achievements in agricultural development in terms of food independence of dairy industry as a whole.

According to official statistics due to food embargo, dairy industry has demonstrated significant reduction of imports on basic dairy products in 2014 for the last three years. It reduced by $23 \%$ with respect to 2012 and by $42 \%$ with respect to 2013. Curd delivery is the subject to the most significant reduction. The reduction accounts for $78 \%$ on the volume of imports for the previous period. (See fig. 3). 


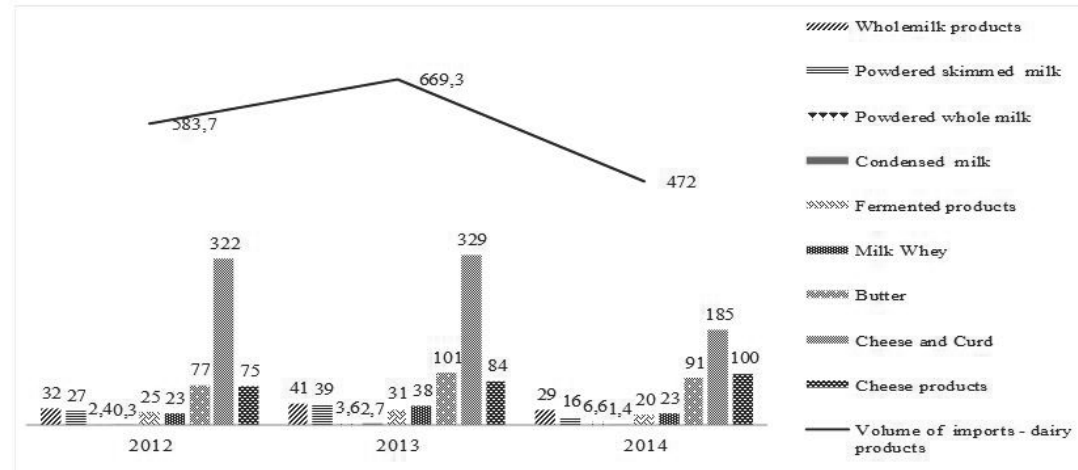

Figure 3. Import figures of basic products within dairy industry, RF, thousand tons. (Completed by the authors, based on materials (Website of National Union of Milk Producers 2015)

Sharp decline in imports by $341,3 \%$ on basic dairy products for the period of five months took place in 2014 owing to imposed food embargo and reached 83, 5 thousand tones. Embargo imposition resulted in nearly full rejection to deliver products manufactured from whole milk to RF from foreign countries and to minimize import of butter, cheese and curd (see fig. 4).

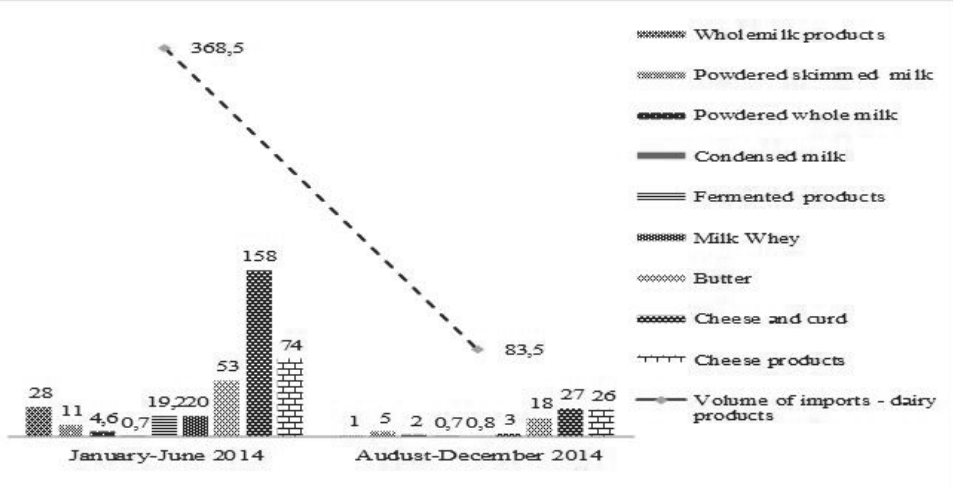

Figure 4. Dynamics of dairy import under embargo in RF, thousand tons. (Completed by the authors, based on materials (Website of National Union of Milk Producers 2015))

The import structure to Russia was represented by relatively narrow assortment, i.e. the biggest share of imported production (up till $79 \%$ ) was represented by cheese and curd (39\%), cheese products (21\%), and butter (19\%). Owing to this fact, sharp import reduction of these product categories turned out to be the major impact of food embargo in Russian dairy industry (see fig.5). 

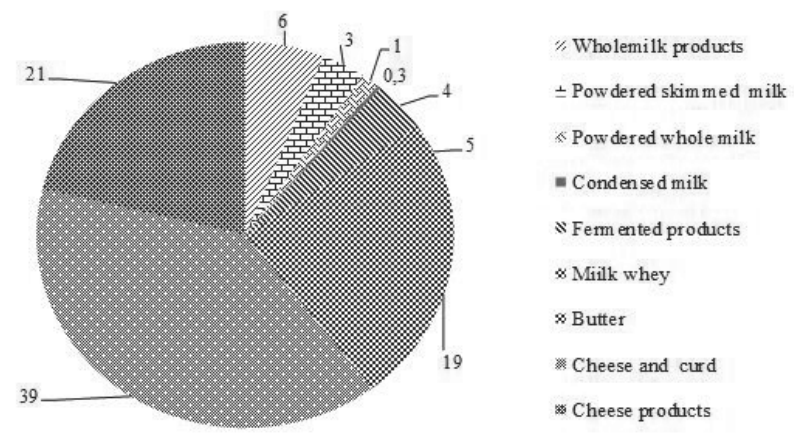

Figure 5. Import structure of dairy industry in RF as of 2014. (Completed by the authors, based on materials (Website of National Union of Milk Producers)

Substantial reduction of butter delivery from foreign countries - major importers of this product as of 2014 in comparison to 2014 can be traced in total imports. Thus, butter delivery under food embargo was completely banned from such countries as Australia, France and Finland by the end of 2014; whereas in 2012 these countries were seen as the leading importers of butter to RF (see fig. 6).

By the end of 2014, such countries as New Zealand, Uruguay and Argentina were major butter importers to Russia. The total scope of delivery accounted for only 19.000 tons in comparison to 41.000 tons in 2012 (see fig. 6).

International delivery of green/fresh cheese and curd to RF was conducted till August 2014 by 10 countriesimporters (see fig. 7) but after imposition of food restrictions, it has been imported form such countries as Argentina, Serbia and Finland, wherein green/fresh cheese and curd import has reduced by 190\% since August 2014.

With regard to delivery of hard cheese, the import reduction in 2014 accounted for $85 \%$ in relation to period of 2012-2013. Such countries as Ukraine (-355\%), Germany (-169\%), France (-166\%) and the Netherlands (-112\%) underwent substantial decrease in import (see fig.8).

The purpose with which food embargo was imposed in Russia was to support national dairy producers in order to decrease the levels of external competition.
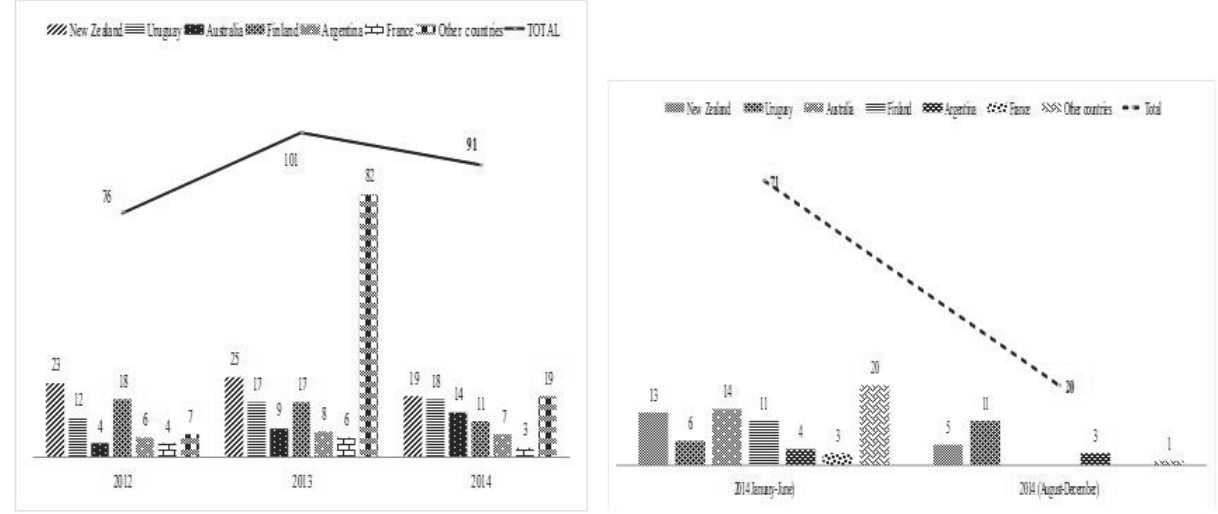

General dynamics of butter import to Russia, thousand tons thousand tons.

Dynamics of butter import to Russia under food embargo,

Figure 6. Indexes of butter imports to RF under food embargo from countries-importers, thousand tons (Completed by the authors, based on materials (Website of National Union of Milk Producers) 

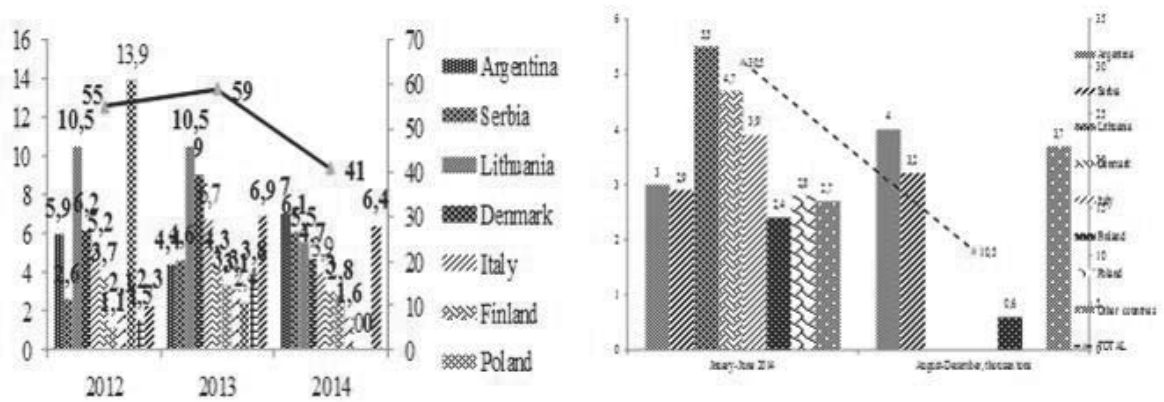

General dynamics of green cheese and curd import to Russia, thousand tons Dynamics of green cheese and curd import to Russia under food embargo, thousand tons

Figure 7. Indexes of green/fresh cheese and curd imports to RF under food embargo from countries-importers, thousand tons (Completed by the authors, based on materials (Website of National Union of Milk Producers))

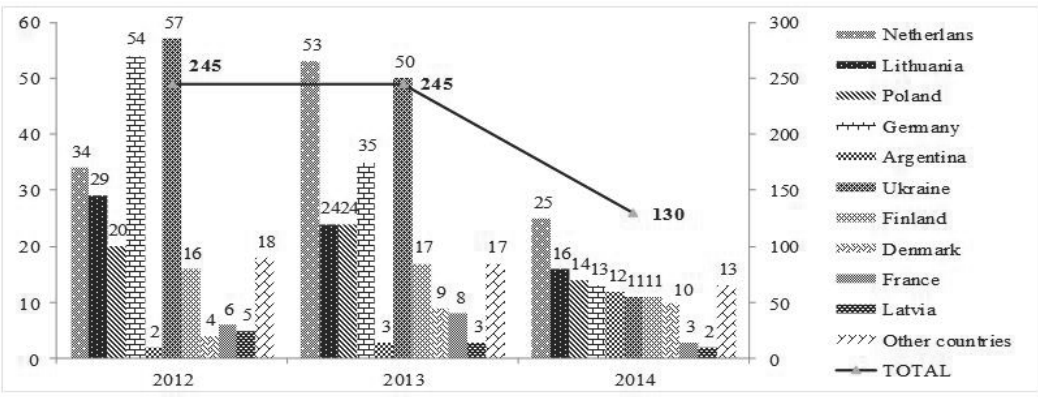

Figure 8. Indexes of semi-hard cheese and hard cheese imports to RF under food embargo from countries-importers, thousand tons. (Completed by the authors, based on materials (Website of National Union of Milk Producers)

Such protectionism could become the starting point for investment inflow in Russian agro-industrial complex in the process of industry development. Nevertheless, this scenario is possible on condition that investors demonstrate intention to increase profitability of agro-industrial sector because of the long time when dairy imports were deterred.

Since high profitability effect of agro-industrial complex can secure sharp price increase on dairy products by means of pouring investment in the industry, the possibility of state price regulation for the period of food embargo remains. Consequently, these measures are able to decrease investment attractiveness of national dairy industry.

Market price determination for dairy products has become priority under food embargo in Russia.

Substantial price increase for raw milk as a base for dairy products was registered after import restraint was imposed according to various data. Price increase for basic dairy products accounted for $70 \%$ compared to as of March, 2015 and 2014 which indicates that the process of price setting passed without state involvement (see fig. 9)

This moderate long-term tendency can attest prospective growth of investment attractiveness within dairy industry. Although, staring from March, 2015, owing to global overproduction of dairy products worldwide, purchase prices fell drastically and reached their critical level (Volkskrant: Exporters to Russia in heavy weather, 2014). Thus, the volume of milk production at the end of 2014 and beginning of 2015 increased by 5, 5\% in EU. In Germany milk prices stay at the level of 33-35 cents for 1 liter, and according to some forecasts, the price is said to go down lower than 30 cents. The prices in Lithuania were 24 cents for 1 liter and in Estonia the prices established at the level of 22-25 cents for 1 liter. Purchase prices in Latvia decreased by 25\% from August 2015 and since beginning of 2015 the prices have gradually been decreasing by another $10 \%$.Alongside with steady decline in prices for the reported period an active growth of production is observed. For example, according to Statistical Office of the European Communities, production rates have grown in Poland by $7 \%$ for the period of 2014 , in the Netherlands by $5-10 \%$ (Statistical Office of the European Communities, 2015). 


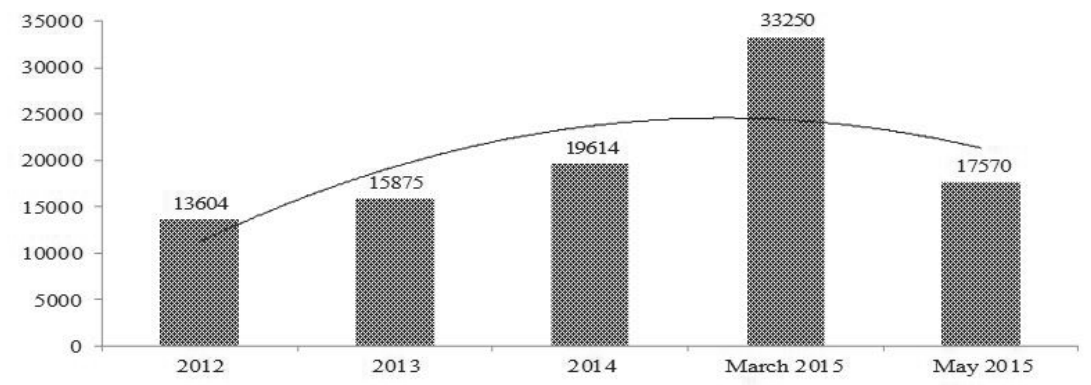

Figure 9. Average annual producer prices of raw milk in RF, RUB, for one tone (Completed by the authors, based on materials (Website of National Union of Milk Producers)

Such tendency could not help reflecting on the current state of dairy industry in RF as a trade partner that is globalized within world external economic environment.

Thus, as for May 2015 the price for 1 liter of milk accounted for 17, 57 RUB and within two months the purchase price of raw milk has decreased by $47,2 \%$, with the total absence of state control over price level in dairy industry (see fig.9).

Price decrease in food industry combined with weak state financial support, as well as high cost of loan capital and absence of potential to attract investment resulted in drastic decrease of milk production in Russia.

Thus, integral index of production levels of basic dairy products such as products manufactured from whole milk, cheese, cheese products, butter, skimmed powdered milk, whole powdered milk, curd, whey powder as of JanuaryMarch 2015 and in comparison to the same period in 2014 decreased by more than 52\% (see fig. 10).

Hereby, based on the foregoing, we can reason that in the circumstances of embargo extension under which national dairy industry has to operate, extrapolation potential to decrease dairy production is formulated within the framework of forced price cuts and provokes the threat of crisis within the dairy industry which can be regarded as a destabilizing factor of the country's security.

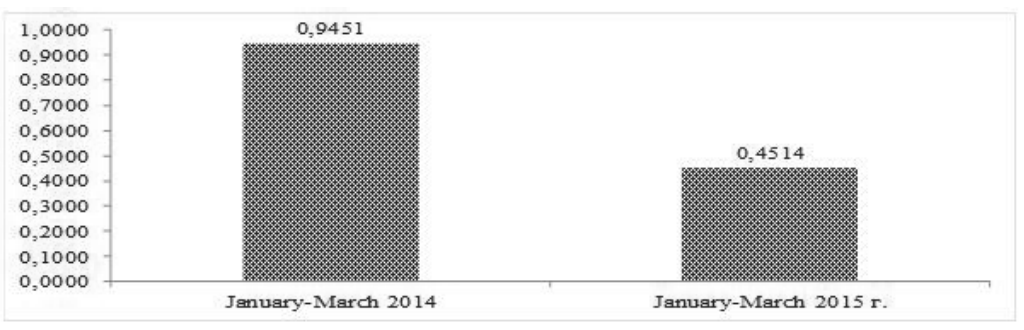

Figure 10. Integral indicator of basic dairy product output in RF. (Completed by the authors, based on materials (Website of National Union of Milk Producers)

Furthermore, decrease or complete abandonment to import dairy products from certain foreign countries without building local technological and financial potential in the industry will lead to the replacement of the importing country (Yermakova and Atabaeva, 2014). For example, with the introduction of import restrictions on cheese, import of cheese from Byelorussia to RF increased by $47 \%$, butter by $27,1 \%$, powdered milk products by $29,6 \%$, and drinking milk by $8,3 \%$ with reference to July, 2014. (Website of the Ministry of Agriculture of RF, 2015; Website of Federal Customs Service))

We consider that in order to increase national dairy industry efficiency it will be advantageous to solve system problems arising in the industry at the most concurrently with the optimization of import substitution process. Together with the current problems arising within the dairy industry under embargo conditions, its position has worsened owing to system factors of functioning during the period of specific economic development for the last years.

Deterioration of equipment /fixed assets can be considered as one of the major problems preventing the industry to 
function successfully (Murtuzalieva and Seifullaeva, 2014). The major part of milk processing plants were constructed and equipped during Soviet period that was 30 years ago. Unfortunately, they have never been modernized yet. Thus, typical milk plants producing cheese products were built in 1970-s and were equipped with the Hungarian machinery "Elgep" (Yermakova and Atabaeva, 2014). According to expert opinions, depreciation of equipment/fixed assets within the industry accounts for $40 \%-80 \%$. Due to high level of wear and tear many enterprises are not able to function at full capacity since use of production capacities does not exceed 30\% in RF (Yermakova and Atabaeva, 2014).

Wear and tear of equipment/fixed assets is accompanied by obsolesce that result in low competitive ability of the whole industry as well as inability to meet customer needs due to low quality and poor assortment (Afonina, 2014).

Together with deterioration of technical base within the industry, there is a low possibility to effectively generate financial resources in the form of cheap borrowed capital and to accumulate sufficient financial base made from state subsidies.

Thus, as for beginning of 2015 state financing of food processing industry accounted for only $0,3 \%$ from GDP. This figure does not cover $5 \%$ of food industry needs in additional capital (Website of the Federal State Statistics Service, 2015).

Industry financing through investments is characterized by low specific weight from the total amount of investment resources in fixed capital of RF - data as of 2014 constituted only 1,8\%, and for 14 previous years investment has decreased by $2 \%$ (see fig. 11).

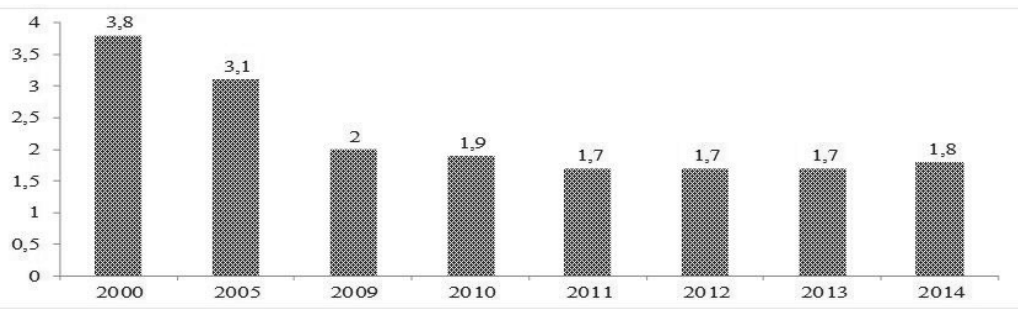

Figure 11. Dynamics of direct capital investment in food processing industry, percent from the total volume of investment in fixed capital. Completed by the authors, based on materials (Website of Federal State Statistics Service, 2015).

On condition that the industry is characterized by low profitability, insufficient amount of working capital/circulating assets, milk producers have to attract additional capital by means of loans . It is worth mentioning that Russian commercial banks have redirected their activities on crediting import-substituting industries under imposition of sanctions by Western countries and embargo as a retaliatory measure, though dairy industry was recognized as unprofitable by credit institutions. That was due to the fact the fact of fast growing delays in loan repayment.

Under these circumstances dairy industry is limited to attract credit-banking resources in order to reproduce economic activity by potential opportunities.

Imperfection of state, customs and tariff regulation of milk market prevents dairy industry from operating effectively. In accordance with the dominant amount of imported goods, the threshold value of their customs value significantly exceeds its average. This causes the imposition of specific duties on the major part of imported dairy goods ceteris paribus.

Positive effect from duty imposition assists in preventing attempts to understate customs value of dairy products but is considerably levelled by the following disadvantages:

Duty rate imposition at an unreasonably high level can lead to ineffective import and consequently, will stimulate illegal or semi-legal import;

This measure can only be short-term since wide usage of specific and combined duties does not completely meet the requirements developed by WTO; 2014).

The intention to restrain/limit cheaper purchases does not always serve the task to support local producers (Piłat,

\section{Discussion}

If all above-mentioned trends considering dairy industry development and operation persist in RF, the process of industry 
deindustrialization and preservation of its current potential will be inevitable.

Dairy industry as well the whole agro and industrial complex needs structure reforms; financial and legal state support. Short-term sanctions imposed for a year cannot be considered as a stimulating factor for industrial activity expansion in dairy industry and does not form the basis for import substitution. Under conditions when industrial technological base has high degree of both obsolesce and wear and tear (deterioration), artificial restriction of competition caused by sanctions can bring only short-term effect.

Within the framework of the study conducted on the basis of identified consequences for dairy industry activities under embargo and due to the specific nature of industry development and peculiarities of Russian economy, we can propose the bundle of optimization measures that will increase dairy industry efficiency.

System development of optimization measures should be based on the principle of emergence executed in the process of corporate management policy realization in dairy industry and state economic policy in food industry. Optimization measures are directed at the solution of three major system problems of agro-industrial complex:

Modernize of the technical base;

Build financial capacity of the industry;

Improve management strategy as a basis for stable activities.

In order to improve technological development strategy of dairy industry we propose:

To establish a new technological set of rules in the industry;

To provide large-scale modernization of production with taking into account the tendencies of world scientific, technological and technical development;

To introduce the latest resource-saving technologies in order to provide process innovation growth;

To develop international scientific and technical cooperation;

To develop integration process between science and technologies;

Constantly record and control indicators of technological safety, to restore promptly their threshold value etc. industry;

The following package of optimization measures provides the foundation for building financial capacity of the

To manage effectively credit and debit indebtedness of enterprises by means of analyzing and restructuring debentures;

To increase investment attractiveness of the industry;

To develop and carry out effective investment strategies;

To attract long-term debt capital on favourable credit terms or by means of using financial assets

The following optimization activities of managerial character should become the priority in the process to ensure competitiveness of dairy industry:

To encourage the development of venture capital investment, leasing, crediting, and high-tech project risk insurance;

To develop a special system of benefits in order to attract investment and investors; products;

To set tax incentives for companies engaged in technical re-equipment and in developing new type of competitive

To improve the regulatory framework of innovation process and to create tax, credit, customs and depreciation benefits to members of the process by providing state support of innovations

To provide large-scale propaganda of healthy way of life and consumption culture of milk and milk products and to ensure further social advertising of dairy products

To carry out purpose-oriented programs aimed at increased milk consumption;

To enter milk and milk products as required into the diet in Russian army;

To provide large-scale inspection activities to monitor dairy products conformity to the labelling standards issued by Technical Regulations on milk and dairy products;

To introduce amendments within Technical Regulations enabling to exonerate/vindicate the term "milk restored from powder milk" and promote it to customers returning their trust to this type of milk ;

To introduce a legal base necessary in order to adopt Technical Regulations;

To introduce UHT milk, butter and hard cheese into the list of products for which purchase interventions can be conducted;

To adopt federal law which will regulate domestic trade mainly in terms of optimization of producers' interaction with retailers;

To prolong credit terms on investment loans received to develop dairy cattle breeding for 15 years;

To decrease rates of import customs duty to zero level for imported technological equipment that is not produced in 


\section{Russia}

\section{Closing}

Thus, within the framework of the empiric research it was stated that short-term food embargo with the duration of one year used as a tool to protect local producer can be considered as a destructive factor for the dairy industry development in current situation.

Significant price decrease on dairy products that lead to decrease of production output within the industry by $50 \%$ caused negative consequences of sharp import restraint accompanied by price police liberalization. It was proved that adverse effect of food embargo would be multiplied by system problems of dairy industry operation. Destructive impact of food embargo under uncertainty of problematic aspects in the system developed within the dairy industry caused the threat of industry crisis as a factor of food security destabilization in RF.

A system of optimization measures was proposed within the framework of the research in order to secure stability and increase efficiency of dairy industry in RF. These optimization measures take the principle of emergency into consideration in order to carry out corporate management policy in the industry and state economic policy in the food industry.

Functional purpose of the measures is expressed in terms of problem solution concerning technical base modernization, building financial capacity of the industry and management strategy improvement as a base of its stability.

Introduction and practical realization of the proposed conceptual optimization measures will become the grounds for revolarisation of industry competiveness under market conditions and will formulate prerequisite for quality improvement of dairy products. All these will lead to stabilization of agro-industrial complex and provision of food security in the country.

\section{References}

Anishenko A. N. (2015). Import Substitution as a factor of Food security provision Economics and Society (2 (15). http://www.iupr.ru/ domains_data/files/zurnal_15/ Anishenko\% 20A.N.\% 200snovnoy \%20razdel.pdf.

Afonina V.E. (2014). Food security and Investment within the context of challenges of modernity/of our days, Internet magazine "Science of Science" (issue 4 (23)). http://naukovedenie.ru/PDF/99EVN414.pdf.

Dairy Industry Development until 2020. Results of diagnostic phase. (2014). http://www.souzmoloko.ru/img2/1_diagnostika.pdf.

Dawe, D. and others. (2015). How much have domestic food prices increased in the new era of higher food prices? I David Dawe, Cristian Morales-Opazo, Jean Balie, Guillaume Pierre, Global Food Security (Vol. 5, pp. 1-10).

Hemme, T. and others. (2014). Benchmarking Cost of Milk Production in 46 Countries / T. Hemme, M. Mohi Uddin, O. Ndambi, Journal of Reviews on Global Economics (N. 3, pp. 254-270).

Hufbauer, G. C. and others. (1990). Economic Sanctions Reconsidered History and Current Policy / Gary Clyde Hufbauer, Jeffrey Schott, Kimberly Ann Elliott. Washington: Institute for International Economics, $835 \mathrm{p}$.

Murtuzalieva, T.V. (2014). Innovation marketing policy of the region, Fundamental science and technology-promising developments. North Charleston, USA, 2014.

Murtuzalieva, T.V., Siefullaeva M. E. (2014). State and prospects of dairy industry development in Russia under Western economic sanctions Gazette of Plekhanov Russian University of Economics (\#. 12 (78), pp. 59-73). Moscow, Russia.

On using certain special measures in order to provide security of Russian Federation (Presidential Order \#560). (2014). http://government.ru/ media/ files/ 41d4f8cdfeeb731522d2.pdf.

On approval of Food and Processing Industry Development Strategy in Russian Federation (Government Decree of Russian Federation April, 172012 года \# 559-p) (2012). gov.spb.ru/static/writable/ckeditor/uploads/../RPFR559S PP2020.doc

On approval of Food Security Doctrine of Russian Federation (Presidential Decree \#120). (2010). http://base.spinform. ru/show_doc. fwx? rgn $=30398$.

Piłat, R. (2014). Russian embargo - history and impact. http://www.kig.pl/files/BWZ/Russian\%20embargo_history\%20and\%20impact_ 2014_pdfx.pdf.

Pylypiv, A. M. and others (2014). Embargo as a tool to improve food security/ Pylypiv, A. M., Panchenko V.V., Grazhganova P.I., Internet magazine "Science of Science " (issue 5 (24)). http://naukovedenie.ru/PDF/145EVN514.pdf.

State Program for the Development of Agriculture and Regulation of Agricultural Markets, Raw materials and Products for 2013-2020. (2015). http://www.mcx.ru/ documents/ document/show/22026.htm.

Statistical Office of the European Communities. (2015). http://epp.eurostat.ec.europa.eu/portal/page/portal/eurostat/home/.

Rating of world milk producers. (2015). http://milknews.ru/analitika-rinkamoloka/reitingi/ reitingi_1082.html? template $=115$.

The Russian Embargo: Impact on the Economic and Employment Situation in the EU. (2014). http://www.europarl.europa.eu/RegData/ etudes/ BRIE/2014/ 536291/IPOL_BRI\%282014\%29536291_EN.pdf.

Volkskrant: Exporters to Russia in heavy weather. (2014). Exporteurs Rusland in zwaar weer, $23 \mathrm{p}$. 
Website of the Ministry of Agriculture of Russian Federation (2015). http://www.mcx.ru/. Website of National Union of Milk Producers (2015). http://www.souzmoloko.ru/souzmoloko/.

Website of Russian Union of Dairy enterprises (2015). http://www.dairyunion.ru/.

Website of Federal State Statistics Service (2015). http://www.gks.ru/.

Website of Federal Customs Service of Russian Federation (2015). http://www.customs.ru/.

Yermakova E. E., Atabaeva, Sh. A. (2014). Current state and prospect of dairy industry development in RF, Young Scientist (\# 7, pp. 338-340). Kazan, Russia.

Zerkalov, D.V. (2009). Food security. Monograph. Kiev: Basis, 2009, 449 p.

Zhiqiang, F. (2013). The National Food Security Research, Advances in Applied Economics and Finance (Vol. 4, N. 1, pp. 646- 651). 